\title{
Pediatric Critical Care: grand challenges for a glowing future
}

\section{Kanwaljeet J. S. Anand*}

Pain Neurobiology Laboratory, Department of Pediatrics, University of Tennessee Neuroscience Institute, University of Tennessee Health Science Center, Memphis, TN, USA

*Correspondence: kanand@uthsc.edu

Edited and reviewed by:

Antonio Francesco Corno, University Sains Malaysia, Malaysia

Keywords: child, infant, critical illness, trauma, pediatric intensive care unit

Pediatric critical care is a relatively new field, tracing its origins to the polio epidemics that killed large numbers of children, birthed by ongoing efforts in pediatric anesthesiology and neonatology, and nourished by parallel advances in pediatric pulmonology, cardiology, nephrology, adult critical care, general, cardiothoracic, neurosurgery, or other fields. Although not many pediatric intensive care units (PICUs) existed before 1980 (Table 1) (13 ), they now occupy a central position in the care of all hospitalized children and in their improved survival from all types of medical/surgical conditions. Despite an overwhelmingly clinical focus and limited avenues for disseminating research, the numbers of PICU-related publications have increased steadily over the past 20 years, currently hovering around 5000 reports per year.

Pediatric Critical Care, a section in the journal Frontiers in Pediatrics, seeks to disseminate the highest quality scholarly activity in this field, thus closing gaps between clinical practices and the highlevel evidence supporting these practices. The four grand challenges include:

1. Fostering innovation in clinical medicine and technology.

2. Translating basic research into new diagnostic/therapeutic tools.

3. Defining short-term and long-term outcomes.

4. Commitments to research, training, and access to care.

\section{FOSTERING INNOVATION IN CLINICAL MEDICINE AND TECHNOLOGY}

Recent discoveries elucidating the mechanisms of critical illness led to substantial advancements in pediatric critical care ( 1 , 2 ), dramatically improving the outcomes of life-threatening illnesses or injuries in childhood. But now is not the time to rest on our laurels! Accelerating progress in multiple fields of biomedical and pharmaceutical sciences, imaging and computational sciences, and biomaterials and bioengineering sciences must be coupled with an unrelenting pursuit of basic science and clinical research to translate these discoveries into improving the care of very sick children. Pediatric intensivists must remain at the forefront of developing or evaluating novel technologies because of their unique perspectives gained from treating the whole patient and family; providing care at the end of life; and exposure to the entire ranges of demographics, medical/surgical conditions, and societal subgroups. Surveying the technological advances available for clinical application is impossible but two examples, regenerative medicine and personalized medicine, are mentioned here.

Innovation is rampant in the interdisciplinary fields of stem-cell therapy and regenerative medicine (4-8), which will significantly impact future treatments for organ failures, metabolic disorders, degenerative conditions, or the long-term sequelae of critical illness. Repair, replacement, or regeneration of various tissues or organs in critical illness is possible but complex (5-7), perhaps using combinations of several approaches including pluripotent stem cells, soluble molecules, genetic/tissue engineering, or advanced cell therapies (9-12). Using autologous bone marrow stem cells to restore cardiac myocytes (1316) or neural stem cells for traumatic or hypoxic brain injury (17-19) will not only save lives but also considerably reduce the costs and side effects of managing chronic organ failure or neurodevelopmental sequelae.
Innovative advances in developmental biology and genetics/genomics will spawn "targeted" or personalized therapies for critical illness (20-22). The current explosion in genetic knowledge will help pediatric intensivists choose the best treatment among existing medicines based on a patient's genetic, demographic, and environmental factors (21). Genetic adrenoceptor variants may dictate our choice of vasopressors and inotropes (23-25) or bronchodilators $(26,27)$, whereas opioid receptor variants may drive our choice of analgesics $(28,29)$. Pediatric intensivists will also have access to genetic tests revealing host susceptibility to specific infections, organ dysfunctions, or non-communicable diseases $(30,31)$. Studies on the human microbiome may help prevent sepsis in immune-compromised children (32) or tracheal infections in chronically ventilated patients (33).

Innovation will not come solely from these areas. Unique tools from clinical informatics can abstract patient data from electronic medical records and link these data with administrative, insurance, educational, or multi-institutional databases providing the statistical power to address previously unanswerable questions (34, 35). Current researchers have the ability to cross-link genomic data with large clinical databases to generate genotypephenotype correlations, thus revealing novel physiological pathways or therapeutic targets. Biopharmaceuticals designed by coupling "-omics" with combinatorial chemistry will allow them to identify previously unknown therapeutic targets. Implantable devices like drug-eluting stents, biodegradable polymers, or other devices will also play an important role in improving the clinical outcomes of PICU patients. 
Table 1 | Early history of pediatric ICUs

\begin{tabular}{lll}
\hline Year & Medical director & Institution \\
\hline 1955 & Dr. Göran Hagland & Göteburg Children's Hospital, Göteburg, Sweden \\
1961 & Dr. Hans Feychting & St. Göran's Hospital, Stockholm, Sweden \\
1963 & Dr. J. B. Joly & Hopital St. Vincent de Paul, Paris, France \\
& Dr. I. H. McDonald & Royal Children's Hospital, Melbourne, Australia \\
1964 & Dr. G. Jackson Rees & Alder Hey Children's Hospital, Liverpool, UK \\
1967 & Dr. John J. Downes & Children's Hospital of Philadelphia, Philadelphia, USA \\
1969 & Dr. Stephan Kampschulte & Children's Hospital of Pittsburgh, Pittsburgh, PA, USA \\
& Dr. James Gilman & Yale-New Haven Medical Center, New Haven, CT, USA \\
1971 & Dr. Donald Clogg & Montreal Children's Hospital, Montreal, Canada \\
& Dr. I. David Todres & Massachusetts General Hospital, Boston, MA, USA \\
1976 & Dr. Alan Conn & Hospital for Sick Children, Toronto, Canada \\
& Dr. Peter Holbrook & Children's National Medical Center, Washington DC, USA \\
& Dr. Mark Rogers & Johns Hopkins University Hospital, Baltimore, MD, USA \\
& Dr. Robert Crone & Children's Hospital Medical Center, Boston, MA, USA \\
& & Le Bonheur Children's Hospital, Memphis, TN, USA
\end{tabular}

\section{TRANSLATING BASIC RESEARCH INTO NEW DIAGNOSTIC/THERAPEUTIC TOOLS}

The route from laboratory research to newer therapeutics or diagnostics is long, difficult, and often fraught with regulatory mishaps or unforeseen obstacles (3638). Examples, where obvious therapeutic targets with excellent pre-clinical data did not translate into safe/effective therapies (39-41), are well-known in critical care, such as immune-based therapies targeting the systemic inflammatory response syndrome or sepsis (42). These disappointments probably resulted from inapt extrapolations of mouse immunology to humans (43), reductionist biological principles (44), or inadequate consideration given to the multi-layered and intricately networked human immune system (4547). Innovative leads to address the problems of integration may come from the Virtual Physiological Human project, which establishes a technological framework for studying the human body as a single complex system $(48,49)$. Large collaborative in silico models will help us to assemble and investigate the entire human physiome, with greater chances for drug discovery leading to therapeutic success than the experimental approaches used previously.

Translational research places greater emphasis on understanding the molecular underpinnings of pediatric critical illness and developing biomarkers with diagnostic/therapeutic relevance. Recent research shows biomarkers associated with specific organ dysfunctions in children, e.g., acute kidney injury $(50,51)$. Specific biomarkers for early organ injury can detect certain diseases at their earliest stages, before the onset of clinical signs or symptoms (5153). Initiating supportive or therapeutic interventions when these diseases are easily treatable or preventable will improve clinical outcomes. Identifying sensitive and specific biomarkers will allow diagnosis, treatment, monitoring, and prevention guided by the patient's molecular signals. Novel biomarkers built into clinical trials can serve as surrogate outcomes or predict the patient's response to therapy.

Given the current environment of less research funding, greater regulatory hurdles, larger clinical studies, and high legal liability, most pharmaceutical companies are reluctant to develop new therapeutics, particularly for a niche market like children. This is a "Grand Challenge" in itself, but there is hope on the horizon. In an unprecedented move, 10 large drug companies and 7 non-profit organizations teamed up with National Institutes of Health (NIH) to develop drugs treating Alzheimer's disease, diabetes, lupus, or rheumatoid arthritis (54). Such partnerships can be formed to tackle the widely prevalent life-threatening diseases like viral bronchiolitis or sepsis in children. To make this happen, however, pediatric intensivists must come up with visionary goals, eloquently articulate them to multiple stakeholders in society, industry, and government, and then deliver excellence in implementing the proposed approaches to tackle these conditions.

\section{DEFINING SHORT-TERM AND LONG-TERM OUTCOMES}

Outcomes research relied on blunt instruments like mortality and morbidity, complications or secondary organ failures, or process outcomes like the length of ICU stay or hospital stay, direct or indirect costs, or quality-of-life parameters. Few studies have focused on measuring other relevant clinical outcomes to provide a more finegrained assessment of patients' response to therapy. Recently, however, newer sources of funding have stimulated greater interest in patient-centered outcomes, functional outcomes, technology/resource utilization, or behavioral and neurodevelopmental outcomes.

Pediatric intensivists must define the most suitable outcomes to test the primary or secondary hypotheses generated in their research, possibly based on physiological (e.g., heart rate variability, microcirculatory flow), molecular [e.g., glycoprotein KL-6 for ARDS (55), neutrophil gelatinase-associated lipocalin (NGAL) for kidney injury (51), shed CD163 for organ dysfunction (56)], or imaging biomarkers [e.g., apparent diffusion coefficient (ADC) using diffusion tensor imaging (57), oxygen extraction fraction (OEF) using positron emission tomography (58)]. Newer end-points can also come from clinical outcomes research, using newer methodologies based on comparative effectiveness, quality improvement, patientcentered outcomes, or population health research. The Patient-Centered Outcomes Research Institute has helped to define objective measures for patient-centered outcomes, such as continuity or satisfaction with care, decisional knowledge, conflict, or regret (59). These novel parameters must be included in classical study designs testing interventions in critically ill children.

Pediatric intensive care, like any other complex, high hazard enterprise (e.g., aviation) was identified as an environment where many adverse events occurred due to human errors (60-62). Investigations to reduce drug-related errors attributed to the "human factor" included, for example, computerized order-entry $(63,64)$, direct observation (65), or $24 / 7$ availability of 
clinical pharmacists (66). However, isolated or piecemeal approaches may have a limited or short-lived effect in reducing human errors unless a safety-based culture is created in the entire hospital. Although initially resource expensive, this multifaceted approach leads to substantial reductions in serious adverse events, preventable harm, or hospital mortality, with some improvements in the safety culture (67). Researchers should explore the possibilities to improve future outcomes in the PICU using quality improvement science to prevent human errors (68).

Long-term functional or psychological outcomes following PICU admission were neglected in many previous studies in children. Examples from cancer and congenital heart surgery have showed the importance of evaluating long-term clinical outcomes (69-71), examining the functional status of children in their home, school, or hospital environment (72). Other long-term outcome measures may include neurodevelopmental or other assessments, but these methods are time consuming, apply to narrow age ranges, and may require specialized training. Newer measures must be objective, relevant, and measure what they are designed for with high sensitivity, specificity, and accuracy, while having strong psychometric properties. The use of disease-based patient registries (73), smart-phone technology, internet access, and social media will allow us to assess long-term clinical outcomes like never before $(74,75)$. The challenge is to develop innovative outcome measures using these tools to effectively assess the long-term consequences of critical illness or PICU therapies in children (76).

\section{COMMITMENTS TO RESEARCH, TRAINING, AND ACCESS TO CARE}

Drug discovery or device development was previously funded by large investments from industry. This paradigm is changing, with increasing costs of drug development, augmented risks of failure in a difficult regulatory environment, unfamiliar drug targets, and increased legal liability, which have reduced the incentives to develop newer agents. Increasingly, biotech or other startup companies with low overhead costs and limited liability are developing drugs/devices, using $\mathrm{R} \& \mathrm{D}$ funds from federal granting agencies, philanthropy, crowdsourcing, or other resources (77, 78). To drive their research agenda, pediatric intensivists must actively collaborate with these companies and their low-cost efforts to test new products. The onus for validating new targets and translating basic science discoveries into commercially viable products is shifting increasingly from industry to academia (77). Academic faculty must forge mutually beneficial partnerships with the biotech industry, to advance their discoveries into new drugs for critically ill children. Early career investigators can develop innovative ways to collaborate with industry, by obtaining specialized molecules or reagents, bioengineered animals, or advanced training at these startup companies.

The pipeline of creative innovators in pediatric critical care will depend on the type of trainees we attract and the research training we offer; both factors are somewhat interdependent $(79,80)$. The challenge is to create an environment that fosters the curiosity, drive, and ambitions of trainees in pediatric critical care. Few departments have created an ecosystem that fosters consistent and sustained success in training new clinician scientists (Figure 1). Without wider commitment, dedicated time, and resources for research, the future growth of our specialty will be stunted and impoverished $(79,81)$. Programs such as the NIH-funded Pediatric Critical Care Scientist Development Program or training grants held by pediatric intensivists at other institutions provide important resources. Commitment to a clinician scientist's career requires intense focus, strong mentorship, and opportunities for scientific growth even after training $(82,83)$. Trainees suited for health services or clinical research, educational research, or other scholarly activities can also provide valuable resources to the specialty.

A shortage of pediatric intensivists exists even in developed countries, with limited coverage in rural or remote areas. Regionalized PICU care increases coverage and controls costs, although for-profit hospitals often set up PICUs because they support a variety of other pediatric programs and services. Deficits in services and infrastructure for PICU care are more acute and widespread in resource-poor nations or international areas with armed conflict. Ensuring that all critically ill children get access to high-quality multidisciplinary intensive care is a huge challenge! Advances in telemedicine and transport medicine are now extending pediatric intensive care to some remote areas (84-86). Remote access to ICU monitors, real-time imaging, live video stream, and electronic medical records via high-speed internet connections allow pediatric intensivists to participate in the care of children located remotely $(85,86)$. Administrative hurdles in terms of medical licensing, patient privacy, malpractice liability, insurance coverage, and reimbursement procedures still need to be overcome in some healthcare markets (87). However, the clinical outcomes of remotely managed patients have not been reported, whereas recent studies show that patients requiring resuscitation or mechanical ventilation had improved outcomes when pediatric intensivists provided in-house coverage (88-90).

Research and policy changes to overcome these obstacles, together with alterations in clinical attitudes, approaches, and outcomes, will provide a rich milieu for research in pediatric critical care knowledge exchange and implementation science (91). Implementation science investigates the behaviors of healthcare professionals, administrators, patients, or other stakeholders as key variables in the uptake, adoption, and implementation of evidence-based interventions $(67,92)$. It can address major bottlenecks (social, behavioral, economic, and management) that impede the effective implementation of current evidence, test new approaches to improve healthcare, or determine causal relationships between an intervention and its clinical impact.

\section{CONCLUSION}

The cumulative burdens of critical illness among children in developing and developed countries give us ample opportunities for research to prevent death, disability, and other limitations that keep children from reaching their full potential. Starting in this Year of the Horse, to be successful in preventing or managing critical illnesses that affect children today, researchers must harness and drive the four horses of innovation, translation, outcomes, and commitments sketched above. The pages of Pediatric Critical Care are eager to record their exploits and glory for posterity. 


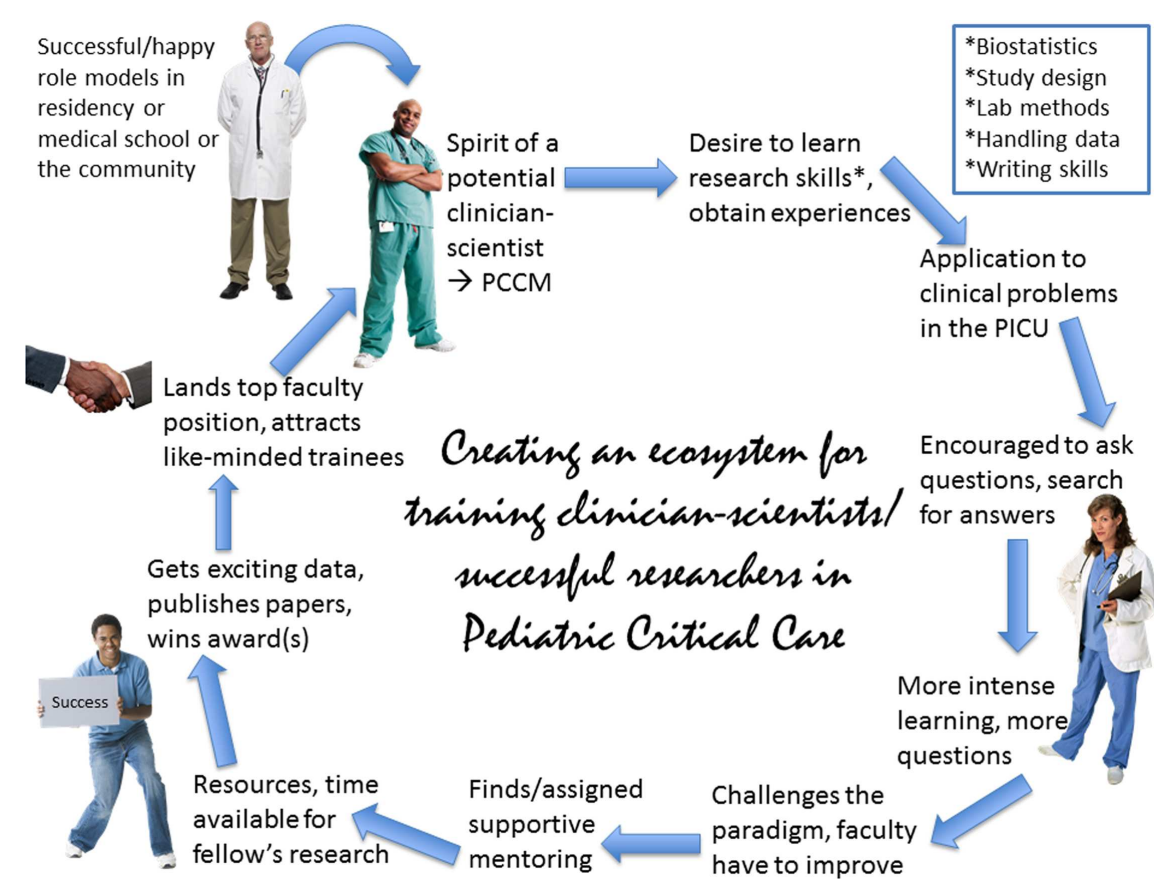

FIGURE 1 | Research-oriented trainees thrive in a challenging and learning environment. Such an environment inspires, nurtures, and prepares trainees to devote their entire career in the pursuit of new knowledge in the basic sciences and/or its clinical applications, or other fields of enquiry. This flow-chart represents the life cycle of such a trainee in a research-oriented department. PCCM, Pediatric Critical Care Medicine; PICU, Pediatric Intensive Care Unit.

\section{ACKNOWLEDGMENTS}

The author sincerely acknowledges the comments and suggestions of Drs. Andreas Schwingshackl, Samir H. Shah, Russell W. Chesney, and Richard W. Hall on earlier versions of this manuscript, as well as the expert guidance of Dr. Antonio Corno during the editorial review.

\section{REFERENCES}

1. Epstein D, Brill JE. A history of pediatric critical care medicine. Pediatr Res (2005) 58:987-96. doi:10.1203/01.PDR.0000182822.16263.3D

2. Mai CL, Schreiner MS, Firth PG, Yaster M. The development of pediatric critical care medicine at The Children's Hospital of Philadelphia: an interview with Dr. John J. 'Jack' Downes. Paediatr Anaesth (2013) 23:655-64. doi:10.1111/pan.12186

3. Contributions of pediatric anesthetists from the UK, Australia, Sweden and France to the early development of pediatric critical care in North America. Soc Pediatr Anesth (2007). Available from: http://www.pedsanesthesia.org/meetings/ 2007annual/syllabus/History/H6-Downes.pdf

4. Gonfiotti A, Jaus MO, Barale D, Baiguera S, Comin C, Lavorini $\mathrm{F}$, et al. The first tissue-engineered airway transplantation: 5-year follow-up results. Lancet (2014) 383:238-44. doi:10.1016/S01406736(13)62033-4

5. Hocking AM. Mesenchymal stem cell therapy for cutaneous wounds. Adv Wound Care (New Rochelle) (2012) 1:166-71. doi:10.1089/wound. 2011.0294
6. Liu YH, Karra R, Wu SM. Cardiovascular stem cells in regenerative medicine: ready for prime time? Drug Discov Today Ther Strateg (2008) 5:201-7. doi:10.1016/j.ddstr.2008.12.003

7. Neuringer IP, Randell SH. Stem cells and repair of lung injuries. Respir Res (2004) 5:6. doi:10.1186/ 1465-9921-5-6

8. Down JD, White-Scharf ME. Reprogramming immune responses: enabling cellular therapies and regenerative medicine. Stem Cells (2003) 21:21-32. doi:10.1634/stemcells.21-1-21

9. Chen KG, Mallon BS, McKay RD, Robey PG. Human pluripotent stem cell culture: considerations for maintenance, expansion, and therapeutics. Cell Stem Cell (2014) 14:13-26. doi:10.1016/j. stem.2013.12.005

10. Walmsley GG, Hyun J, McArdle A, Senarath-Yapa $\mathrm{K}$, Hu MS, Chung MT, et al. Induced pluripotent stem cells in regenerative medicine and disease modeling. Curr Stem Cell Res Ther (2014) 9:73-81. doi:10.2174/1574888X09666131217004137

11. Jung DW, Kim WH, Williams DR. Reprogram or reboot: small molecule approaches for the production of induced pluripotent stem cells and direct cell reprogramming. ACS Chem Biol (2014) 9:80-95. doi:10.1021/cb400754f

12. van den Bos C, Keefe R, Schirmaier C, McCaman M. Therapeutic human cells: manufacture for cell therapy/regenerative medicine. Adv Biochem Eng Biotechnol (2014) 138:61-97. doi:10.1007/10_ 2013_233

13. Loughran JH, Chugh AR, Ismail I, Bolli R. Stem cell therapy: promising treatment in heart failure? Curr Heart Fail Rep (2013) 10:73-80. doi:10.1007/ s11897-012-0128-2
14. Haraguchi Y, Shimizu T, Yamato M, Okano T. Concise review: cell therapy and tissue engineering for cardiovascular disease. Stem Cells Transl Med (2012) 1:136-41. doi:10.5966/sctm.2012-0030

15. Fuh E, Brinton TJ. Bone marrow stem cells for the treatment of ischemic heart disease: a clinical trial review. J Cardiovasc Transl Res (2009) 2:202-18. doi:10.1007/s12265-009-9095-8

16. Chachques JC, Salanson-Lajos C, Lajos P, Shafy A, Alshamry A, Carpentier A. Cellular cardiomyoplasty for myocardial regeneration. Asian Cardiovasc Thorac Ann (2005) 13:287-96. doi:10.1177/ 021849230501300322

17. McGlynn M. StemCells, Inc.: clinical trials of stem cell therapies for CNS disorders. Interview with Martin McGlynn. Regen Med (2012) 7:8-11. doi:10.2217/rme.12.81

18. Bhasin A, Srivastava MV, Mohanty S, Bhatia R, Kumaran SS, Bose S. Stem cell therapy: a clinical trial of stroke. Clin Neurol Neurosurg (2013) 115:1003-8. doi:10.1016/j.clineuro.2012.10.015

19. Harris DT. Non-haematological uses of cord blood stem cells. Br J Haematol (2009) 147:177-84. doi: 10.1111/j.1365-2141.2009.07767.x

20. Binesh Marvasti T, D'Alessandro LC, Manase D, Papaz T, Mital S. Personalized medicine in the care of the child with congenital heart disease: discovery to application. Congenit Heart Dis (2013) 8:266-9. doi:10.1111/chd.12061

21. Becker ML, Leeder JS. Identifying genomic and developmental causes of adverse drug reactions in children. Pharmacogenomics (2010) 11:1591-602. doi:10.2217/pgs.10.146

22. Hesselink DA, van Schaik RH, Nauta J, van Gelder T. A drug transporter for all ages? ABCB1 and the 
developmental pharmacogenetics of cyclosporine. Pharmacogenomics (2008) 9:783-9. doi:10.2217/ 14622416.9.6.783

23. Chen W, Srinivasan SR, Hallman DM, Berenson GS. The relationship between birth weight and longitudinal changes of blood pressure is modulated by beta-adrenergic receptor genes: the Bogalusa Heart Study. J Biomed Biotechnol (2010) 2010:543514. doi:10.1155/2010/543514

24. Snieder H, Dong Y, Barbeau P, Harshfield GA, Dalageogou $\mathrm{C}$, $\mathrm{Zhu} \mathrm{H}$, et al. Beta2-adrenergic receptor gene and resting hemodynamics in European and African American youth. Am J Hypertens (2002) 15:973-9. doi:10.1016/S0895-7061(02)02991-6

25. Krushkal J, Xiong M, Ferrell R, Sing CF, Turner ST, Boerwinkle E. Linkage and association of adrenergic and dopamine receptor genes in the distal portion of the long arm of chromosome 5 with systolic blood pressure variation. Hum Mol Genet (1998) 7:1379-83. doi:10.1093/hmg/7.9.1379

26. Palmer CN, Lipworth BJ, Lee S, Ismail T, Macgregor DF, Mukhopadhyay S. Arginine-16 beta2 adrenoceptor genotype predisposes to exacerbations in young asthmatics taking regular salmeterol. Tho$\operatorname{rax}(2006)$ 61:940-4. doi:10.1136/thx.2006.059386

27. Tsai HJ, Shaikh N, Kho JY, Battle N, Naqvi M, Navarro D, et al. Beta 2-adrenergic receptor polymorphisms: pharmacogenetic response to bronchodilator among African American asthmatics. Hum Genet (2006) 119:547-57. doi:10.1007/ s00439-006-0169-2

28. Anand KJ, Willson DF, Berger J, Harrison R, Meert $\mathrm{KL}$, Zimmerman J, et al. Tolerance and withdrawal from prolonged opioid use in critically ill children. Pediatrics (2010) 125:e1208-25. doi:10.1542/peds. 2009-0489

29. Kolesnikov Y, Gabovits B, Levin A, Voiko E, Veske A. Combined catechol-O-methyltransferase and mu-opioid receptor gene polymorphisms affect morphine postoperative analgesia and central side effects. Anesth Analg (2011) 112:448-53. doi:10. 1213/ANE.0b013e318202cc8d

30. Overby CL, Tarczy-Hornoch P, Hoath JI, Kalet IJ, Veenstra DL. Feasibility of incorporating genomic knowledge into electronic medical records for pharmacogenomic clinical decision support. $B M C$ Bioinformatics (2010) 11(Suppl 9):S10. doi:10. 1186/1471-2105-11-S9-S10

31. Chen DP, Weber SC, Constantinou PS, Ferris TA, Lowe HJ, Butte AJ. Novel integration of hospital electronic medical records and gene expression measurements to identify genetic markers of maturation. Pac Symp Biocomput (2008) 2008:243-54.

32. Garland SM, Tobin JM, Pirotta M, Tabrizi SN, Opie G, Donath S, et al. The ProPrems trial: investigating the effects of probiotics on late onset sepsis in very preterm infants. BMC Infect Dis (2011) 11:210. doi:10.1186/1471-2334-11-210

33. Berdal JE, Bjornholt J, Blomfeldt A, Smith-Erichsen N, Bukholm G. Patterns and dynamics of airway colonisation in mechanically-ventilated patients. Clin Microbiol Infect (2007) 13:476-80. doi:10. 1111/j.1469-0691.2006.01678.x

34. Teufel RJ II, Kazley AS, Ebeling MD, Basco WT Jr. Hospital electronic medical record use and cost of inpatient pediatric care. Acad Pediatr (2012) 12:429-35. doi:10.1016/j.acap.2012.06.004
35. Anonymous. American Academy of Pediatrics: task force on medical informatics. Special requirements for electronic medical record systems in pediatrics. Pediatrics (2001) 108:513-5. doi:10.1542/ peds.108.2.513

36. Mathis LL, Iyasu S. Safety monitoring of drugs granted exclusivity under the Best Pharmaceuticals for Children Act: what the FDA has learned. Clin Pharmacol Ther (2007) 82:133-4. doi:10.1038/sj. clpt.6100285

37. Rappaport B, Mellon RD, Simone A, Woodcock J. Defining safe use of anesthesia in children. N Engl J Med (2011) 364:1387-90. doi:10.1056/ NEJMp1102155

38. Rappaport N, Prince JB, Bostic JQ. Lost in the black box: juvenile depression, suicide, and the FDA's black box. J Pediatr (2005) 147:719-20. doi:10.1016/j.jpeds.2005.08.037

39. Manocha S, Feinstein D, Kumar A. Novel therapies for sepsis: antiendotoxin therapies. Expert Opin Investig Drugs (2002) 11:1795-812. doi:10.1517/ 13543784.11.12.1795

40. Cometta A, Baumgartner JD, Glauser MP. Polyclonal intravenous immune globulin for prevention and treatment of infections in critically ill patients. Clin Exp Immunol (1994) 97(Suppl 1):69-72.

41. Dinarello CA, Gelfand JA, Wolff SM. Anticytokine strategies in the treatment of the systemic inflammatory response syndrome. JAMA (1993) 269:1829-35. doi:10.1001/jama.1993.03500140081040

42. Nee PA, Rivers EP. The end of the line for the Surviving Sepsis Campaign, but not for early goaldirected therapy. Emerg Med J (2011) 28:3-4. doi:10.1136/emj.2010.097147

43. Davis MM. A prescription for human immunology. Immunity (2008) 29:835-8. doi:10.1016/j. immuni.2008.12.003

44. Ahn AC, Tewari M, Poon CS, Phillips RS. The limits of reductionism in medicine: could systems biology offer an alternative? PLoS Med (2006) 3:e208. doi:10.1371/journal.pmed.0030208

45. Peterson LW, Artis D. Intestinal epithelial cells: regulators of barrier function and immune homeostasis. Nat Rev Immunol (2014) 14:141-53. doi:10. $1038 /$ nri3608

46. Liston A, Gray DH. Homeostatic control of regulatory T cell diversity. Nat Rev Immunol (2014) 14:154-65. doi:10.1038/nri3605

47. Poon IK, Lucas CD, Rossi AG, Ravichandran KS. Apoptotic cell clearance: basic biology and therapeutic potential. Nat Rev Immunol (2014) 14:166-80. doi:10.1038/nri3607

48. Viceconti M, Clapworthy G, Testi D, Taddei F, McFarlane N. Multimodal fusion of biomedical data at different temporal and dimensional scales. Comput Methods Programs Biomed (2011) 102:227-37. doi:10.1016/j.cmpb.2010.04.017

49. Viceconti M, Clapworthy G, Van Sint Jan S. The Virtual Physiological Human - a European initiative for in silico human modelling. J Physiol Sci (2008) 58:441-6. doi:10.2170/physiolsci. RP009908

50. Andreoli SP. Acute kidney injury in children. Pediatr Nephrol (2009) 24:253-63. doi:10.1007/ s00467-008-1074-9
51. Makris K, Rizos D, Kafkas N, Haliassos A. Neutrophil gelatinase-associated lipocalin as a new biomarker in laboratory medicine. Clin Chem Lab Med (2012) 50:1519-32. doi:10.1515/cclm-20120227

52. Buelow MW, Dall A, Regner K, Weinberg C, Bartz PJ, Sowinski J, et al. Urinary interleukin-18 and urinary neutrophil gelatinase-associated lipocalin predict acute kidney injury following pulmonary valve replacement prior to serum creatinine. Congenit Heart Dis (2012) 7:441-7. doi:10.1111/j. 1747-0803.2012.00662.x

53. Slort PR, Ozden N, Pape L, Offner G, Tromp WF, Wilhelm AJ, et al. Comparing cystatin C and creatinine in the diagnosis of pediatric acute renal allograft dysfunction. Pediatr Nephrol (2012) 27:843-9. doi:10.1007/s00467-011-2073-9

54. Kolata G. An Unusual Partnership to Tackle Stubborn Diseases. The New York Times (New York edition, Health Section) (2014); Vol. 163, Issue 56,038, p. A14.

55. Briassoulis G, Mavrikiou M, Margeli A, Lazaropoulou C, Natsi L, Papassotiriou I, et al. Circulating levels of KL-6 in acute respiratory distress syndrome sepsis or traumatic brain injury in critically ill children. Pediatr Pulmonol (2006) 41:790-5. doi:10.1002/ppul.20465

56. Ingels C, Moller HJ, Hansen TK, Wouters PJ, Vanhorebeek I, Van den Berghe G. Circulating levels of the shed scavenger receptor sCD163 and association with outcome of critically ill patients. J Clin Immunol (2013) 33:619-29. doi:10.1007/s10875012-9830-9

57. Newcombe VF, Williams GB, Nortje J, Bradley PG, Chatfield DA, Outtrim JG, et al. Concordant biology underlies discordant imaging findings: diffusivity behaves differently in grey and white matter post acute neurotrauma. Acta Neurochir Suppl (2008) 102:247-51. doi:10.1007/978-3-21185578-2_47

58. Coles JP, Fryer TD, Smielewski P, Rice K, Clark JC, Pickard JD, et al. Defining ischemic burden after traumatic brain injury using 150 PET imaging of cerebral physiology. J Cereb Blood Flow Metab (2004) 24:191-201. doi:10.1097/01.WCB. 0000100045.07481.DE

59. Siow E, Wypij D, Berry P, Hickey P, Curley MA. The effect of continuity in nursing care on patient outcomes in the pediatric intensive care unit. $J$ Nurs Adm (2013) 43:394-402. doi:10.1097/NNA. 0b013e31829d61e5

60. Agarwal S, Classen D, Larsen G, Tofil NM, Hayes LW, Sullivan JE, et al. Prevalence of adverse events in pediatric intensive care units in the United States. Pediatr Crit Care Med (2010) 11:568-78. doi:10.1097/PCC.0b013e3181d8e405

61. Ream RS, Mackey K, Leet T, Green MC, Andreone TL, Loftis LL, et al. Association of nursing workload and unplanned extubations in a pediatric intensive care unit. Pediatr Crit Care Med (2007) 8:366-71. doi:10.1097/01.PCC. 0000269379.40748.AF

62. Nichter MA. Medical errors affecting the pediatric intensive care patient: incidence, identification, and practical solutions. Pediatr Clin North Am (2008) 55:757-77,xii. doi:10.1016/j.pcl.2008. 02.014 
63. Vaidya V, Sowan AK, Mills ME, Soeken K, Gaffoor $\mathrm{M}$, Hilmas E. Evaluating the safety and efficiency of a CPOE system for continuous medication infusions in a pediatric ICU. AMIA Annu Symp Proc (2006) 2006:1128.

64. Sowan AK, Mohamed G, Soeken K, Mills ME, Johantgen M, Vaidya V. A comparison of medication administrations errors using CPOE orders vs. handwritten orders for pediatric continuous drug infusions. AMIA Annu Symp Proc (2006) 2006:1105.

65. Buckley MS, Erstad BL, Kopp BJ, Theodorou AA, Priestley G. Direct observation approach for detecting medication errors and adverse drug events in a pediatric intensive care unit. Pediatr Crit Care Med (2007) 8:145-52. doi:10.1097/01. PCC.0000257038.39434.04

66. Kaushal R, Bates DW, Abramson EL, Soukup JR, Goldmann DA. Unit-based clinical pharmacists' prevention of serious medication errors in pediatric inpatients. Am J Health Syst Pharm (2008) 65:1254-60. doi:10.2146/ajhp070522

67. Brilli RJ, McClead RE Jr, Crandall WV, Stoverock L, Berry JC, Wheeler TA, et al. A comprehensive patient safety program can significantly reduce preventable harm, associated costs, and hospital mortality. J Pediatr (2013) 163:1638-45. doi:10.1016/j.jpeds.2013.06.031

68. Federwisch M, Ramos H, Adams SC. The sterile cockpit: an effective approach to reducing medication errors? Am J Nurs (2014) 114:47-55. doi:10. 1097/01.NAJ.0000443777.80999.5c

69. Chrysostomou C, Morell VO, Kuch BA, O’Malley E, Munoz R, Wearden PD. Short- and intermediateterm survival after extracorporeal membrane oxygenation in children with cardiac disease. J Thorac Cardiovasc Surg (2013) 146:317-25. doi:10.1016/j. jtcvs.2012.11.014

70. Shiraishi S, Uemura H, Kagisaki K, Hagino I, Kobayashi J, Takahashi M, et al. Long-term results of total cavopulmonary connection with low ejection fraction. Gen Thorac Cardiovasc Surg (2011) 59:686-92. doi:10.1007/s11748-0110812-2

71. McGrath E, Wypij D, Rappaport LA, Newburger JW, Bellinger DC. Prediction of IQ and achievement at age 8 years from neurodevelopmental status at age 1 year in children with D-transposition of the great arteries. Pediatrics (2004) 114:e572-6. doi:10.1542/peds.2003-0983-L

72. Pollack MM, Holubkov R, Glass P, Dean JM, Meert KL, Zimmerman J, et al. Functional Status Scale: new pediatric outcome measure. Pediatrics (2009) 124:e18-28. doi:10.1542/peds. 2008-1987

73. Vitale MG, Vitale MA, Lehmann CL, Hyman JE, Roye DP Jr, Skaggs DL, et al. Towards a National Pediatric Musculoskeletal Trauma Outcomes Registry: the Pediatric Orthopaedic Trauma Outcomes Research Group (POTORG) experience. J Pediatr Orthop (2006) 26:151-6. doi:10.1097/01.bpo. 0000218520.98244 .37
74. Nsanzimana S, Ruton H, Lowrance DW, Cishahayo S, Nyemazi JP, Muhayimpundu R, et al. Cell phone-based and internet-based monitoring and evaluation of the National Antiretroviral Treatment Program during rapid scale-up in Rwanda: TRACnet, 2004-2010. J Acquir Immune Defic Syndr (2012) 59:e17-23. doi:10.1097/QAI. 0b013e31823e2278

75. Gentles SJ, Lokker C, McKibbon KA. Health information technology to facilitate communication involving health care providers, caregivers, and pediatric patients: a scoping review. J Med Internet Res (2010) 12:e22. doi:10.2196/jmir.1390

76. Weinberger $M$, Weinberger $M H$, Fineberg $N$, Fineberg SE, Wagner U. Long-term followup of participants in clinical studies. J Clin Epidemiol (2002) 55:230-4. doi:10.1016/S08954356(01)00437-1

77. Smith CD. Your idea and your university: issues in academic technology transfer. J Investig Med (2011) 59:752-7. doi:10.231/JIM.0b013e31820d0fdf

78. Burns LR, Housman MG, Robinson CA. Market entry and exit by biotech and device companies funded by venture capital. Health Aff (Millwood) (2009) 28:w76-86. doi:10.1377/hlthaff.28.1.w76

79. Morrison WE, Helfaer MA, Nadkarni VM. National survey of pediatric critical care medicine fellowship clinical and research time allocation. Pediatr Crit Care Med (2009) 10:397-9. doi:10.1097/PCC.0b013e318198b14b

80. Powner DJ, Thomas EA. Research curricula in critical care fellowships - a survey. Crit Care Med (1996) 24:1079-82. doi:10.1097/00003246199606000-00032

81. Anderson MR, Jewett EA, Cull WL, Jardine DS, Outwater KM, Mulvey HJ. Practice of pediatric critical care medicine: results of the Future of Pediatric Education II survey of sections project. Pediatr Crit Care Med (2003) 4:412-7. doi:10.1097/01. PCC.0000090288.43781.23

82. Henrickson S, Altshuler D. Risk and return for the clinician-investigator. Sci Transl Med (2012) 4:135cm6. doi:10.1126/scitranslmed.3004110

83. Rosenblum ND, Bazett-Jones DP, O’Brodovich H A scientist track investigator program to support early career outcomes for clinician scientists. J Pediatr (2009) 155(603-4):el. doi:10.1016/j.jpeds. 2009.07.047

84. Webb CL, Waugh CL, Grigsby J, Busenbark D, Berdusis K, Sahn DJ, et al. Impact of telemedicine on hospital transport, length of stay, and medical outcomes in infants with suspected heart disease: a multicenter study. J Am Soc Echocardiogr (2013) 26:1090-8. doi:10.1016/j.echo.2013. 05.018

85. Marcin JP, Nesbitt TS, Kallas HJ, Struve SN, Traugott CA, Dimand RJ. Use of telemedicine to provide pediatric critical care inpatient consultations to underserved rural Northern California. J Pediatr (2004) 144:375-80. doi:10.1016/j.jpeds.2003. 12.017
86. Marcin JP, Nesbitt TS, Struve S, Traugott C, Dimand RJ. Financial benefits of a pediatric intensive care unit-based telemedicine program to a rural adult intensive care unit: impact of keeping acutely ill and injured children in their local community. Telemed J E-Health (2004) 10(Suppl 2):S-1-5.

87. Dharmar M, Sadorra CK, Leigh P, Yang NH, Nesbitt TS, Marcin JP. The financial impact of a pediatric telemedicine program: a children's hospital's perspective. Telemed J E-Health (2013) 19:502-8. doi:10.1089/tmj.2012.0266

88. Carroll CL, Sala K, Fisher D, Zucker A. Pediatric code events: does in-house intensivist coverage improve outcomes?*. Pediatr Crit Care Med (2014) 15:250-7. doi:10.1097/PCC. 0000000000000056

89. Iannucci GJ, Oster ME, Chanani NK, Gillespie SE, McCracken CE, Kanter KR, et al. The relationship between in-house attending coverage and nighttime extubation following congenital heart surgery*. Pediatr Crit Care Med (2014) 15:258-63. doi:10.1097/PCC.0000000000000068

90. Parshuram CS, Kirpalani H, Mehta S, Granton J, Cook D. In-house, overnight physician staffing: a cross-sectional survey of Canadian adult and pediatric intensive care units. Crit Care Med (2006) 34:1674-8. doi:10.1097/01.CCM. 0000218808.13189.E7

91. Wolbrink TA, Kissoon N, Burns JP. The development of an internet-based knowledge exchange platform for pediatric critical care clinicians worldwide*. Pediatr Crit Care Med (2014) 15:197-205. doi:10.1097/PCC.0000000000000051

92. Whitney G, Daves S, Hughes A, Watkins S, Woods $M$, Kreger M, et al. Implementation of a transfusion algorithm to reduce blood product utilization in pediatric cardiac surgery. Paediatr Anaesth (2013) 23:639-46. doi:10.1111/pan.12126

Conflict of Interest Statement: The author declares that the research was conducted in the absence of any commercial or financial relationships that could be construed as a potential conflict of interest.

Received: 12 March 2014; accepted: 16 April 2014; published online: 30 April 2014.

Citation: Anand KJS (2014) Pediatric Critical Care: grand challenges for a glowing future. Front. Pediatr. 2:35. doi: 10.3389/fped.2014.00035

This article was submitted to Pediatric Critical Care, a section of the journal Frontiers in Pediatrics.

Copyright (c) 2014 Anand. This is an open-access article distributed under the terms of the Creative Commons Attribution License (CC BY). The use, distribution or reproduction in other forums is permitted, provided the original author(s) or licensor are credited and that the original publication in this journal is cited, in accordance with accepted academic practice. No use, distribution or reproduction is permitted which does not comply with these terms. 